\title{
Pengaruh Status Sosial Ekonomi dan Perhatian Orang Tua terhadap Prestasi Belajar Bahasa Indonesia
}

\author{
Johan Syah \\ Fakultas Pascasarjana Universitas Indraprasta PGRI \\ Jalan Nangka No. 58 C/TB. Simatupang, Tanjung Barat, Jakarta Selatan 12530 \\ johansyah.1982@gmail.com
}

\begin{abstract}
The purpose of this research is to study the socioeconomic status and parents' attention to Indonesian learning achievement. The research method used was a descriptive research method by taking a sample of 64 grade VIII students of the 2017/2018 school year who came from two State MTs of Indramayu Regency. The results of this study indicate that: 1) There are significant differences in socioeconomic status and parental attention together towards the learning achievement of Indonesian students of MTs Negeri Indramayu Regency. This is evidenced by the acquisition of a score of Sig. The socioeconomic status variable and the attention of these parents together contributed to the variability of learning achievement in Indonesian by 28\%. 2) There is a significant influence on the socioeconomic status of the learning achievement of Indonesian students of MTs Negeri Indramayu Regency. This was proved by agreement of Sig.0.032 $<0.05$ and tcount $=2.198$. The contribution of socioeconomic status variables in improving the achievement of learning Indonesian is $12.2 \%$. 3) Make a significant contribution to parents of the Indonesian language learning achievement students of MTs Negeri Indramayu Regency. This is proven by agreeing to the value of Sig.0.010 $<0.05$ and tcount $=2.650$. parents' attention in increasing the achievement of learning Indonesian by $15.7 \%$.
\end{abstract}

Keywords: parents 'socioeconomic status, parents' attention, Indonesian learning achievement.

\begin{abstract}
Abstak
Tujuan dari penelitian ini adalah untuk mengetahui pengaruh status sosial ekonomi dan perhatian orang tua terhadap prestasi belajar bahasa indonesia. Metode penelitian yang digunakan adalah metode survei deskriptif dengan mengambil sampel sebanyak 64 siswa kelas VIII tahun ajaran 2017/2018 yang berasal dari dua MTs Negeri Kabupaten Indramayu. Hasil Penelitian ini menunjukkan bahwa: 1) Terdapat pengaruh yang signifikan status sosial ekonomi dan perhatian orang tua secara bersama-sama terhadap prestasi belajar bahasa Indonesia siswa MTs Negeri Kabupaten Indramayu Hal ini dibuktikandenganperolehan nilaiSig.0,000 <0,05danF $\mathrm{F}_{\text {hitung }}=11.745$. Variabel status sosial ekonomi dan perhatian orang tua ini secara bersama-sama memberikan kontribusikepadavariabelprestasi belajar bahasa Indonesia sebesar28\%. 2) Terdapat pengaruh yang signifikan status sosial ekonomi terhadapprestasi belajar bahasa Indonesia siswa MTs Negeri Kabupaten Indramayu. Halinidibuktikan dengan perolehannilaiSig.0,032<0,05dan $t_{\text {hitung }}=2,198$. Kontribusi variabel status sosial ekonomi dalam meningkatkan prestasi belajar bahasa Indonesiasebesar 12,2\%.3) Terdapat pengaruhyang signifikan perhatian orang tua terhadapprestasi belajar bahasa Indonesia siswa MTs Negeri Kabupaten Indramayu. Halini dibuktikan dengan perolehan nilaiSig. $0,010<0,05$ dan $t_{\text {hitung }}=2,650$. kontribusiperhatian orang tua dalam meningkatkan prestasi belajar bahasa Indonesia sebesar $15,7 \%$.
\end{abstract}

Kata Kunci: status social ekonomi orang tua, perhatian orangtua, prestasi belajar bahasa Indonesia 


\section{PENDAHULUAN}

Pendidikan merupakan investasi masa depan orang tua kepada anaknya. Berbagai macam cara dilakukan orang tua untuk melakukan apa pun agar anak yang menjadi titipan Tuhan Yang Maha kuasa dapat berkembang dengan baik serta mampu menjawab segala tantangan yang akan mereka hadapi di kemudian hari. Pendidikan adalah tanggung jawab orang tua atau keluarga. Menurut Santoso dalam (Riana, 2011) menyatakan bahwa keluarga terkait pengembangan manusia Indonesia punya kedudukan yang sangat strategis sesuai dengan tuntutan zaman. Sejak dini orang tua dapat menanamkan nilai-nilai modernitas pada anak agar nantinya seiring berjalnnya waktu dapat mengembangkannya lagi. Lingkungan keluarga (orang tua) merupakan pusat pendidikan pertama dan utama bagi seorang anak terkait status sosial-ekonominya. Keluarga adalah proses penentu dalam keberhasilan belajar anak. Orang tua sebagai pendidik pertama karena orang tualah yang mendidik anaknya sejak dalam kandungan hingga kelak anaknya tumbuh dewasa.

Prestasi belajar Bahasa Indonesia dapat dipengaruhi oleh faktor perhatian dari orang tua. Menurut (Desmita, 2012) hubungan orang tua dengan anak yang suportif, memungkinkan untuk dapat membantu perkembangan kompetensi sosial dan otonomi yang bertanggung jawab. Hubungan orang tua dan anak yang suportif merupakan bentuk perhatian dari orang tua kepada anak dalam jalinan komunikasi sehingga dimungkinkan anak akan terbuka dan berterus terang terhadap apa yang ia lakukan dalam kegiatannya.

Selain perhatian dalam bentuk hubungan suportif, menurut (Chatib, 2012) orang tua juga harus melakukan discoveringability kepada anaknya, menjelajah kemampuan anak sekecil apa pun karena akan berdampak positif bagi pekembangan anak. Discovering ability merupakan bentuk perhatian orang tua kepada anaknya dengan cara mencari tahu atau mencari informasi mengenai apa pun yang telah dicapai oleh anak. Pencapaian yang diperoleh anak perlu selalu diberi perhatian oleh orang tua karena pencapaian merupakan bentuk hasil kerja anak selama proses belajarnya.

Orang tua juga perlu memberi perhatian dalam bentuk yang lain, yaitu berupa dorongan dalam bentuk moril kepada anak. Dorongan secara moril merupakan injeksi energi positif kepada anak untuk selalu berbuat maksimal dalam pencapaiannya. Dengan begitu, anak akan terbakar semangatnya dari dalam dirinya sendiri yang akan selalu memotivasi dirinya sendiri untuk selalu berprestasi dalam belajarnya.

Adapun hasil dari pencapaian prestasi belajar pada anak dapat diukur dan dilihat dari nilai hasil belajarnya yang termuat dalam buku laporan pendidikan Penilaian Akhir Semester (PAS). Dari hasil nilai-nilai tersebut kemudian dijadikan dasar sebagi indikator untuk mengukur kemampuan siswa dalam menguasai pelajaran pada jenjangnya. Atas dasar urain tersebut, penulis tertarik melakukan penelitian tentang pengaruh status sosial ekonomi dan perhatian orang tua terhadap prestasi belajar Indonesia (Survey pada siswa MTs Negeri di Kabupaten Indramayu).

\section{Landasan Teori}

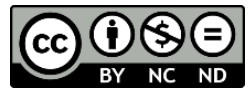




\section{Pengertian belajar}

Belajar sebagai suatu aktivitas mental/psikis dalam lingkungan yang berlangsung secara interaksi aktif. Perubahan itu bersifat relatif dan berbekas. Winkel menyimpulkan belajar sebagi sebuah proses perubahan pada diri seseorang akibat dari pengalaman dan latihan-latihan yang terencana. Paling sedikit terdapat 5 macam perilaku sebagi penyebab atau factor-faktor dasar dalam belajar. Pertama, tingkat emosional yang "primitif' berubah diakibatkan oleh stimulus tak terkondisi dan stimulus terkondisi. Kedua, belajar kontinuitas yaitu dua peristiwa dipasangkannya satu dengan yang lainnya dalam satu waktu. Ketiga, belajar opera yaitu konsekuensi dari satu perilaku akan menentukan apakah perilaku itu akan diulangi atau tidak dan seberapa besar pengulangan itu. Keempat, hasil observasi manusia dan kejadian-kejadian merupakan pengalaman belajar. Kelima, belajar kognitif terjadi apabila melihat dan memahami peristiwa-peristiwa di sekitar, serta dengan belajar menyelami pengertian (Winkel, 2011).

Intinya, belajar adalah "perubahan". Oleh karena itu, seseorang yang melakukan aktivitas belajar dan memperoleh perubahan dalam dirinya dengan memperoleh pengalaman baru, maka dikatakan individu itu telah belajar. Menurut (Soekamto \& Winataputra, 1997) menyimpulkan definisi belajar sebagai berikut: "(1) belajar harus mencakup tingkah laku (2) perubahan tingkah laku pada tingkat paling sederhana sampai komlplek, (3) kontrol segala proses perubahan tingkah laku secara sendiri atau dikendalikan oleh faktor-faktor dari luar".

\section{Prestasi Belajar}

Prestasi belajar adalah "seseorang yang mampu berpikir dengan sempurna, merasa, dan berbuat. Ada 3 aspek yang harus terpenuhi terkait prestasi belajar, yakni kemampuan berpikir, bersikap, dan keterampilan bertindak, begitupun sebaliknya, dapat dikatakan kurang memuaskan."(Nasution, 2006).

Setiap individu sesuai dengan nalurinya berkeinginan untuk berprestasi baik di sekolah, maupun di masyarakat. Keinginan atau kebutuhan semacam ini sebenamya dalam rangka meningkatkan harga diri sebagai individu. Prestasi belajar di sekolah merupakan rnasalah yang penting dibahas, sebab prestasi menunjukkan keberhasilan studi peserta didik ditinjau dari segi kognisinya, sedangkan dari segi sikap psikomotor dapat dikaitkan di balik keberhasilan yang didapat. Sebagai dugaan sementara bahwa peserta didik yang hasil belajarnya baik berarti tujuan pengajaran dan pendidikan juga tercapai.

Dapat disimpulkan bahwa prestasi belajar adalah nilai yang dapat dicapai oleh seseorang dengan kemampuan maksimal setelah seseorang tersebut mengikuti kegiatan pembelajaran.

\section{Hakikat status sosial ekonomi orang tua Pengertian orang tua}

Manusia hidup di lingkungan rumah, yaitu keluarga, terdiri dari ayah, ibu, dan anakanak mereka. Ayah dan ibu itulah yang disebut orang tua yang akan bertanggung jawab untuk merawat, mendidik, dan membesarkan anak-anaknya hingga mereka mampu hidup mandiri. UU RI No. 1 tahun 1974 Bab X mengungkapkan tentang "Hak dan Kewajiban Orang Tua dan Anak"pasal 45 ayat (1) yang berbunyi "Kedua 
orang tua wajib memelihara dan mendidik anak-anak mereka sebaik-baiknya". Serta ayat (2) yang berbunyi "Kewajiban orang tua yang dimaksud dalam ayat (1) dalam pasal ini berlaku sampai anak itu menikah atau berdiri sendiri, kewajiban masih berlaku terus meskipun perkawinan antara kedua orang tua putus" (Presiden Republik Indonesia, 1974). Pendidikan orang tua terhadap anak-anaknya adalah pendidikan yang didasarkan pada rasa kasih sayang terhadap anak-anaknya dan diterimanya dari kodrat (Purwanto, 2002). Orang tua merupakan area terdekat pada individu. Anak sangat memerlukan kasih sayang, perlindungan, rasa aman, sikap dan perlakuan yang adil dari orang tua. Oleh karena itu, kasih sayang orang tua terhadap anak-anaknya hendaklah kasih sayang yang sejati pula.

\section{Pengertian status ekonomi}

Kata status menurut KBBI (Badan Pengembangan dan Pembinaan Bahasa, 2016) adalah keadaan atau kedudukan (orang, badan, dan sebagainya) dalam hubungannya dengan masyarakat di sekelilingnya. Sedangkan status sosial adalah kata turunan dari status yang berarti posisi seseorang di dalam masyarakat yang terkait dengan dan ditentukan oleh orang lain. Ekonomi adalah berasal dari kata ekos dan nomos yang berarti rumah tangga; secara harfiah keadaan rumah tangga. Pendapat lain mengatakan bahwa status sosial ekonomi merupakan faktor fisik yang dapat memengaruhi hasil pada anak-anak. Status sosial ekonomi mempunyai pengertian bahwa makna suatu keadaan yang menunjukkan kemampuan finansial sebuah keluarga dan material yang dimilki (Winkel, 1991).

Jadi, dapat disimpulkan bahwa status sosial ekonomi adalah kedudukan seseorang atau keluarga di masyarakat berdasarkan pendapatan per bulan, yang dapat dilihat dari pola kehidupan sehari-hari, misalnya berpakaian, pergaulan, mengisi waktu luang, tempat tinggal, mengisi rumah kediaman, dan seterusnya. Hal-hal tersebut dapat memengaruhi prestasi yang akan diperoleh atau dicapai oleh anak-anak mereka.

\section{Pengertian Perhatian Orang Tua}

Menurut (Suryabrata, 2007) "Perhatian diartikan sebagai banyak sedikitnya kesadaran yang menyertai sesuatu aktivitas yang dilakukan”. Menurut (Baharuddin \& Esa, 2009) "Perhatian merupakan pemusatan atau konsentrasi dari seluruh aktivitas individu yang ditunjukkan kepada suatu sekumpulan objek". Perhatian orang tua adalah suatu pemusatan aktivitas tenaga psikis didukung tenaga fisik ayah dan ibu siswa atau wali yang mengasuh dan membiayai serta sebagai penanggung jawab siswa disertai adanya kesadaran tertuju pada suatu objek. Perhatian orang tua yang dimaksud dalam penelitian ini adalah pemusatan energi yang dilakukan dengan sengaja, intensif dan terkonsentrasi dari orang tua yang dilandasi rasa penuh kesadaran dalam melakukan tindakan demi prestasi belajar anaknya.

\section{Macam-Macam Perhatian Orang Tua Pemberian Bimbingan Belajar}

Memberikan bimbingan belajar terhadap anak pada dasarnya membantu anak dalam menentukan pilihan-pilihan yang bijaksana terkait penyesuaian diri atas tuntutan hidup, agar anak nantinya proses belajarnya lebih terarah dan bertanggung 
jawab. Hal itu merupakan sebagai kemampuan diri untuk mengiplementasikan pengetahuan secar efektif dan potensi berkembang dengan baik meliputi kepribadian sebagai individu yang sangat potensial.

\section{Memberikan Nasihat}

Nasihat merupakan bentuk lain dari perhatian orang tua kepada anak. Saran atau nasihat merupakan alat untuk memcahkan masalah, berdasarkan pengetahuan, pengalaman dan pikiran sehat. Kesadaran akan hakikat sesuatu serta mendorong mereka untuk melakukan sesuatu perbuatan yang baik dapat diperoleh melalui nasihat-nasihat atu petuah dan itu sangat berdampak besar serta membuka mata anak-anak.

\section{Memberikan Motivasi dan Penghargaan}

Untuk menumbuhkan perilaku tertentu dan tujuan tertentu juga perlu adanya dorongan dalam bentuk motivasi. Hal itu membuktikan bahwa kecerdasan intelektual tanpa adanya motivasi untuk meningkatkan prestasi belajar hasilnya tidak akan memuaskan. Oleh karena itu, perlu adanya motivasi dan penghargaan orang tua terhadap anaknya untuk meraih cita-citanya.

\section{Memenuhi Kebutuhan Anaknya}

Bagi anak pemenuhan kebutuhan adalah sesuatu yang sangat penting karena hal itu akan mempermudah anak untuk belajar dengan baik. Dalam hal ini (Walgito, 1990) menyatakan bahwa "kelengkapan peralatan dalam belajar akan membantu anak untuk belajar dengan baik, begitu pun sebaliknya, maka jika itu terjadi boleh dikatan merupakan gangguan dalam belajar.

\section{Pengawasan Terhadap Anaknya}

Orang tua dalam melakukan pengawasan terhadap anak lebih kepada masalah belajar. Dengan melakukan pengawasan itu, orang tua akan mengetahui kesulitan belajar anak dan segala yang terkait dengan kebutuhan belajar. Dengan demikian, orang tua dapat memaksimalkan proses belajar anak, agar dapat meraih prestasi yang baik. Pengawasan terhadap anak oleh orang tua bukan bentuk pengekangan, tetapi lebih kepada pengawasan akan tanggung jawab anak terhadap belajar.

\section{METODE}

Metode penelitian yang digunakan adalah survei deskriptif. Yaitu suatu metode penelitian yang mengambil sampel dari suatu populasi dan menggunakan kuesioner sebagai alat pengumpulan data" (Akdon \& Ridwan, 2006). "Kuesioner adalah sejumlah pertanyaan tertulis yang digunakan untuk memperoleh informasi dari responden dalam arti laporan tentang pribadinya atau hal-hal yang ia ketahui" (Arikunto, 2010). Data dari hasil kuesioner kemudian dianalisis secara deskriptif.

Metode penelitian survei adalah usaha pengamatan untuk mendapatkan keterangan-keterangan yang jelas terhadap suatu masalah tertentu dalam suatu penelitian dilakukan secara meluas dan berusaha mencari hasil yang segera dapat 


\section{Diskursus: Jurnal Pendidikan Bahasa Indonesia}

Vol. 1, No. 2, Agustus 2018, pp. 154-164

p-ISSN: 2615-4935

e-ISSN: 2615-4943

dipergunakan untuk suatu tindakan yang sifatnya deskriptif yaitu menggambarkan hal-hal yang mengandung fakta-fakta, klasifikasi, dan pengukuran.

\section{HASIL DAN PEMBAHASAN}

\section{Hasil}

Dari pengujian hipotesis yang di bantu dengan program SPSS versi 2.0 dihasilkan data sebagai berikut

\section{Tabel 1. Hasil Perhitungan Pengujian Koefisien Korelasi Ganda Variabel $X_{1}$ dan $\mathrm{X}_{2}$ terhadap $\mathrm{Y}$}

Model Summary

\begin{tabular}{|l|l|r|r|r|}
\hline Model & $\mathrm{R}$ & R Square & $\begin{array}{c}\text { Adjusted R } \\
\text { Square }\end{array}$ & $\begin{array}{c}\text { Std. Error of } \\
\text { the Estimate }\end{array}$ \\
\hline 1 & $.527^{\mathrm{a}}$ & .278 & .254 & 7.730 \\
\hline
\end{tabular}

a. Predictors: (Constant), Perhatian orang tua, Status sosial ekonomi

Tabel 2. Hasil Perhitungan Pengujian Signifikansi Koefisien Regresi Variabel $X_{1}$ dan $X_{2}$ terhadap $Y$

ANOVA ${ }^{\mathrm{a}}$

\begin{tabular}{|ll|r|r|r|r|r|}
\hline Model & & $\begin{array}{c}\text { Sum of } \\
\text { Squares }\end{array}$ & df & Mean Square & F & Sig. \\
\hline 1 & Regression & 1403.689 & 2 & 701.844 & 11.745 & $.000^{\text {b }}$ \\
& Residual & 3645.249 & 61 & 59.758 & & \\
& Total & 5048.938 & 63 & & & \\
\hline
\end{tabular}

a. Dependent Variable: Prestasi belajar bhs Indonesia

b. Predictors: (Constant), Perhatian orang tua, Status sosial ekonomi

Coefficients $^{a}$

\begin{tabular}{|c|c|c|c|c|c|c|}
\hline \multirow{2}{*}{\multicolumn{2}{|c|}{ Model }} & \multicolumn{2}{|c|}{ Unstandardized Coefficients } & \multirow{2}{*}{$\begin{array}{c}\begin{array}{c}\text { Standardized } \\
\text { Coefficients }\end{array} \\
\text { Beta } \\
\end{array}$} & \multirow[b]{2}{*}{$t$} & \multirow[b]{2}{*}{ Sig. } \\
\hline & & $\mathrm{B}$ & Std. Error & & & \\
\hline \multirow[t]{3}{*}{1} & (Constant) & 4.177 & 14.765 & & .283 & .778 \\
\hline & Status sosial ekonomi & .253 & .115 & .276 & 2.198 & .032 \\
\hline & Perhatian orang tua & .301 & .114 & .333 & 2.650 & .010 \\
\hline
\end{tabular}

a. Dependent Variable: Prestasi belajar bhs Indonesia

1. Pengaruh status sosial ekonomi $\left(\mathrm{X}_{\mathrm{I}}\right)$ dan perhatian orang tua $\left(\mathrm{X}_{2}\right)$ secara bersama-sama terhadap prestasi belajar bahasa Indonesia (Y).

Hipotesis yang diuji:

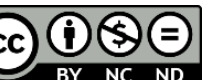


Ho: $\beta y_{1}=\beta y_{2}=0$

$H_{1}: \beta y_{1} \neq 0, \beta y_{2}=0$

Artinya:

Ho: tidak terdapat pengaruh status sosial ekonomi dan perhatian orang tua secara bersama-sama terhadap prestasi belajar Bahasa Indonesia

$\mathrm{H}_{1}$ : terdapat pengaruh status sosial ekonomi dan perhatian orang tua secara bersama-sama terhadap prestasi belajar Bahasa Indonesia

Dari tabel di atas dapat dinyatakan bahwa terdapat pengaruh yang signifikan status sosial ekonomi dan perhatian orang tua secara bersama-sama terhadap prestasi belajar Bahasa Indonesia. Hal ini dibuktikan dengan perolehan nilaiSig. $0,000<0,05$ dan $F_{\text {hitung }}=11,745$.

Sementara itu, persamaan garis regresi ganda dapat dinyatakan dengan $\hat{\mathrm{Y}}=4,177+0,253 \mathrm{XI}+0,301 \mathrm{X} 2$. Hal ini memiliki pengertian bahwa kenaikan nilai variable status sosial ekonomi dan perhatian orang tua memberikan kontribusi sebesar 0,253 oleh X1 dan 0,301 oleh X2 terhadap variabel prestasi belajar bahasa Indonesia. Dari tabel di atas juga dapat menjelaskan bahwa secara bersama-sama variabel status sosial ekonomi dan perhatian orang tua memberikan kontribusi sebesar $28 \%$ terhadap variable prestasi belajar Bahasa Indonesia.

2. Pengaruh status sosial ekonomi orang tua $\left(\mathrm{X}_{1}\right)$ terhadap prestasi belajar Bahasa Indonesia( $(Y)$

Hipotesis yang diuji:

Ho: $\beta y_{1}=0$

$H_{1}: \beta y_{1} \neq 0$

Artinya:

$\mathrm{H}_{0}$ : tidak terdapat pengaruh status sosial ekonomi terhadap prestasi belajar Bahasa Indonesia.

$\mathrm{H}_{1}$ : terdapat pengaruh status sosial ekonomi terhadap prestasi belajar Bahasa Indonesia.

Dari table di atas dapat dinyatakan bahwa terdapat pengaruh yang signifikan status sosial ekonomi terhadap prestasi belajar Bahasa Indonesia. Hal ini dibuktikan dengan perolehan nilai Sig.0,032<0,05 dan $t_{\text {hitung }}=2,198$. Adapun kontribusi status sosial ekonomi terhadap prestasi belajar Bahasa Indonesia dapat dinyatakan dengan rumus:

$\mathrm{KD}=\mathrm{Nilai} \beta X 1 Y \quad \mathrm{X}$ Nilai Korelasi Pasialnya $\left(r_{\mathrm{X} 1 \mathrm{Y}}\right) \quad \mathrm{X} 100 \%$ $\mathrm{KD}=0,276 \times 0,441 \times 100 \%=12,2 \%$

Dari hasil perhitungan di atas dapat dinyatakan bahwa kontribusi status sosial ekonomi orang tua dalam meningkatkan prestasi belajar Bahasa Indonesia sebesar12,2\% 
3. Pengaruh perhatian orang tua $\left(\mathrm{X}_{2}\right)$ terhadap prestasi belajar bahasa Indonesia (Y)

Hipotesis yang diuji:

Ho: $\beta_{y l}=0$

$H_{1}: \beta_{y l} \neq 0$

Artinya:

Ho: tidak terdapat pengaruh perhatian orang tua terhadap prestasi belajar bahasa Indonresia.

$\mathrm{H}_{1}$ : terdapat pengaruh perhatian orang tua terhadap prestasi belajar Bahasa Indonesia.

Dari di atas dapat dinyatakan bahwa terdapat pengaruh yang signifikan perhatian orang tua terhadap prestasi belajar Bahasa Indonesia. Hal ini dibuktikan dengan perolehan nilaiSig. $0,010<0,05$ dan $t_{\text {hitung }}=2,650$. Adapun kontribusi variabel perhatian orang tua terhadap prestasi belajar bahasa Indonesia dinyatakan dengan rumus:

$\mathrm{KD}=$ Nilai $\beta_{X 2 Y} \mathrm{XNilaiKorelasi} \mathrm{Pasialnya}\left(r_{x 2 y}\right) \mathrm{X} 100 \%$

$\mathrm{KD}=0,333 \times 0,470 \times 100 \%=15,7 \%$

Dari hasil perhitungan di atas dapat dinyatakan bahwa kontribusi perhatian orang tua dalam meningkatkan prestasi belajar bahasa Indonesia sebesar $15,7 \%$.

\section{Pembahasan}

Pengaruh status social ekonomi $\left(X_{1}\right)$ dan perhatian orang tua $\left(\mathbf{X}_{2}\right)$ secara bersama-sama terhadap prestasi belajar bahasa Indonesia (Y).

Hasil penelitian di atas menunjukkan bahwa status social ekonomi dan perhatian orang tua secara bersama-sama dapat memberikan pengaruh positif terhadap prestasi belajar bahasaIndonesia siswa MTs Negeri kelas VIII Kabupaten Indramayu. Halini berarti bahwa status sosial ekonomi yang mapan dan perhatiam orang tua yang tinggi telah memberikan pengaruh yang signifikan terhadap prestasi belajar Bahasa lndonesia siswa MTs Negeri Kabupaten Indramayu.

Secara umum faktor yang dapat mempengaruhi prestasi belajar adalah faktor external dan internal. Faktor external antara lain penyajian materi ajar, teknik pengajaran, keterampilan mengajar dan sikap guru, serta faktor internal yang mendukung terjadinya proses pembelajaran baik di sekolah maupun di luar sekolah, sedangkan faktor internal seperti sikap, motivasi, minat belajar dan perhatian orang tua siswa juga memegang peran penting untuk meningkatkan prestasi belajar bahasa Indonesia siswa.

Menurut sintesis teori yang ada, siswa memerlukan berbagai dukungan baik bersifat materi maupun nonmateri. Faktor status sosial merupakan faktor penting yang dapat memenuhi kebutuhan siswa tersebut sehingga dapat mempengaruhi prestasi belajar siswa. 
Berdasarkan kodrat-Nya manusia dilahirkan memiliki kedudukan yang sama dan sederajat. Akan tetapi sesuai dengan kenyataan setiap yang menjadi warga suatu masyarakat, senantiasa mempunyai status atau kedudukan dan peranan. Ada beberapa faktor yang dapat menentukan tinggi rendahnya keadaan tingkat status sosial ekonomi di masyarakat, di antaranya tingkat pendidikan, jenis pekerjaan, tingkat pendapatan, kondisi lingkungan tempat tinggal, pemilikan kekayaan dan partisipasi dalam aktivitas kelompok dari komunitasnya. Dengan demikian, jika status sosial ekonomi baik, maka diasumsikan bahwa prestasi belajar siswa akan baik juga. Namun, jika ternyata tingkat status sosial ekonomi rendah, maka yang terjadi pada prestasi belajar akan kurang juga.

Faktor lainnya adalah perhatian orang tua, seperti yang disampaikan Bagus Santoso (Santoso, 2010) yaitu pemusatan kesadaran jiwa berupa tenaga, pikiran dan perasaan, dari orang tua kepada anaknya, ditransformasikan dalam berbagai cara untuk memberikan motivasi atau dorongan positif terhadap anaknya dalam usaha mencapai prestasi belajar yang optimal. Orang tua mempunyai pengaruh yang cukup besar terhadap proses belajar siswa. Semakin besar perhatian orang tua terhadap proses belajar anak, maka semakin tinggi pula prestasi belajar anak dan sebaliknya. Perhatian orang tua tidak hanya bermakna bagi proses belajar siswa, tetapi juga memberikan umpan balik bagi pencapaian tujuan-tujuan yang diharapkan. Selain itu, dapat digunakan untuk mengukur sampai sejauh mana keefektifan pengalaman belajar siswa.

\section{Pengaruh status social ekonomi $\left(\mathrm{X}_{1}\right)$ terhadap prestasi belajar Bahasa Indonesia (Y).}

Hasil penelitian di atas menunjukkan bahwa status sosial ekonomi telah memberikan pengaruh terhadap prestasi belajar bahasa Indonesia siswa MTs Negeri Kabupaten Indramayu.Status social ekonomi adalah suatu keadaan kehidupan dan penghidupan sosial, material, maupun spiritual yang diliputi rasa keselamatan, kesusilaan dan ketenteraman lahir batin. Secara materi, orang tua yang status sosialnya baik mampu memenuhi kebutuhan anaknya untuk kepentingan pendidikan.

Berdasarkan pengertian di atas, selanjutnya dikembangkan indikator yang mencerminkan tingkat status sosial ekonomi yang baik. Indikator tersebut sangat bermanfaat untuk memantau kemampuan orang tua dalam mendukung proses pendidikan anaknya. Faktor-faktor yang menentukan tingkat status sosial eknomiberdasarkan kodrat-Nya manusia dilahirkan memiliki kedudukan yang sama dan sederajat, tetapi sesuai dengan kenyataan setiap yang menjadi warga suatu masyarakat, senantiasa mempunyai status atau kedudukan dan peranan yang berbeda. Ada beberapa faktor yang dapat menentukan tinggi rendahnya keadaan status sosial ekonomi, diantaranya tingkat pendidikan, jenis pekerjaan, tingkat pendapatan, kondisi lingkungan tempat tinggal, pemilikan kekayaan dan partisipasi dalam aktivitas kelompok dari komunitasnya. Dari uraan teoretis tersebut bisa diasumsikan bahwa semakin tinggi tingkat status sosial ekonomi, maka semakin tinggi pula kemampuan orang tua dalam memenuhi kebutuhan anaknya yang sedang mengikuti proses pendidikan. Dengan bantuan dan dukungan dari orang tua maka prestasi belajar yang baik bisa diraihnya. 


\section{Pengaruh perhatian orang tua $\left(\mathrm{X}_{2}\right)$ terhadap Prestasi belajar Bahasa Indonesia (Y).}

Usaha-usaha yang dapat dilakukan untuk membina hubungan orang tua dan anak yang pada akhirnya diharapkan dapat menumbuhkan, membina dan mengembangkan potensi anak. Dalam memberi perhatian orang tua seyogyanya dapat menyensuaikan kondisi anaknya sehingga pola perhatian yang diberikan dapat berhasil dengan baik. Menurut (Slameto, 2010) menjelaskan bahwa "Cara orang tua mendidik anaknya besar pengaruhnya terhadap belajar anaknya", jadi keberhasilan belajar anak juga dipengaruhi oleh pola asuh orang tua. Pola asuh orang tua berbeda-beda antara satu dengan yang lain. Pola asuh orang tua ada yang bersifat overprotection (terlalu melindungi), permissiveeness (memberikan kebebasan), rejection (acuh tak acuh), acceptence (kasih sayang yang tulus), domination (mendominasi anak), sibmission (memanjakan) dan overdiciplin.

Perhatian orang tua yang diberikan kepada anaknya dalam belajar akan membangkitkan gairah belajar anak karena anak akan merasa diperhatikan dan didukung dalam belajar. Anak selalu merasa mendapat perhatian orang tuanya dan merasa aman. Perhatian orang tua tidak cukup dengan melengkapi keperluan sarana dan prasarana belajar, melainkan kebutuhan perhatian, kepedulian dan rasa kasih sayang serta pengayoman sehingga anak dapat belajar dengan tenang dan penuh dengan semangat untuk belajar dengan sungguh-sungguh karena mendapat apresiasi dari kedua orang tua, anak lebih termotivasi untuk belajar dan mencapai prestasi belajar yang tinggi.

\section{SIMPULAN}

Dari pembahasan dan hasil penelitian dapat disimpulkan bahwa:

1. Terdapatnya pengaruh yang signifikan status sosial ekonomi dan perhatian orang tua secara bersama-sama terhadap prestasi belajar bahasa Indonesia siswa MTs Negeri Kabupaten Indramayu. Hal ini dibuktikan dengan perolehan nilai Sig. $0,000<0,05$ dan $F_{\text {hitung }}=11,745$. Secara bersama-sama variabel status sosial ekonomi dan perhatian orang tua memberikan kontribusi sebesar $28 \%$ terhadap variabel prestasi belajar bahasa Indonesia.

2. Terdapatnya pengaruh yang signifikan status sosial ekonomi orang tua terhadap prestasi belajar bahasa Indonesia siswa MTs Negeri Kabupaten Indramayu. Hal ini dibuktikan dengan perolehan nilai Sig.0,032<0,05 dan $t_{\text {hitung }}=2,198$. Kontribusi yang diberikan variabel status sosial ekonomi terhadap prestasi belajar bahasa Indonesia sebesar 12,2\%.

3. Terdapatnya pengaruh yang signifikan perhatian orang tua terhadap prestasi belajar bahasa Indonesia siswa MTs Negeri Kabupaten Indramayu. Hal ini dibuktikan dengan perolehan nilai Sig.0,010<0,05 dan $t_{\text {hitung }}=2,650$. Variabel perhatian orang tua ini memberikan kontribusi pada prestai belajar bahasa Indonesia sebesar $15,7 \%$. 


\section{DAFTAR PUSTAKA}

Akdon, \& Ridwan. (2006). Aplikasi statistika dan metode penelitian untuk administrasi dan manajemen. Bandung: Dewa Ruci.

Arikunto, S. (2010). Prosedur penelitian suatu pendekatan praktik. Jakarta: Rineka Cipta.

Badan Pengembangan dan Pembinaan Bahasa. (2016). Kamus Besar Bahasa Indonesia. Jakarta: Badan Pengembangan dan Pembinaan Bahasa.

Baharuddin, \& Esa, N. . (2009). Teori belajar dan pembelajaran. Yogyakarta: ArRuzz Media.

Chatib, M. (2012). Orang tuanya manusia. Jakarta: Kaifa.

Desmita. (2012). Psikologi perkembangan peserta didik. Bandung: PT Remaja Rosda Karya.

Nasution. (2006). Pendekatan dalam proses belajar dan mengajar. Jakarta: Bumi Aksara.

Presiden Republik Indonesia. Undang-Undang Republik Indonesia Nomor 1 Tahun 1974 tentang Perkawinan. , (1974).

Purwanto, N. (2002). Psikologi pendidikan. Bandung: PT Remaja Rosda Karya.

Riana. (2011). Kedudukan keluarga sangat startegis dalam mendidik anakanaknya. Bandung: CV Pustaka Setia.

Santoso, B. (2010). Korelasi antara perhatian orang tua dengan prestasi belajar pendidikan kewarganegaraan pada siswa kelas V SDN Gembongan Sentolo Kulon Progo tahun 2010. UNY.

Slameto. (2010). Belajar dan faktor-aktor yang mempengaruhinya. Jakarta: Rineka Cipta.

Soekamto, T., \& Winataputra, U. S. (1997). Teori belajar dan model-model pembelajaran. Jakarta: Dirjen Dikti, Depdikbud.

Suryabrata, S. (2007). Psikologi pendidikan (Suatu pengajaran secara operasional. Yogyakarta: Rake Press.

Walgito, B. (1990). Psikologi sosial. Yogyakarta: Andi.

Winkel, W. S. (1991). Psikologi pengajaran. Jakarta: Gramedia.

Winkel, W. S. (2011). Kedudukan Keluarga Sangat Startegis dalam mendidik anak-anaknya. 